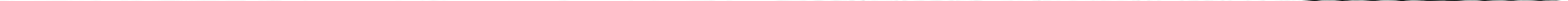


Procress Report

Trafflc Speed Report INo. 82

TO: G. A. Leonards, Director

Joint H1 thway Research Project

December 9, 1965

Fule: $8-3-4$

Project: C-36-10D

FROM: H. L. Michael, Associate Director

Joint H1 ghway Research Project

Attached is a Progress Report entitled "Trafflc Speed Report IIo. 82", conducted in August and September of 1965. The report was prepared by Mr. Darrell A. Wright, Graduate Assistant on our staff, under the directIon of Professor H. L. Michael.

This report contasing the results of the 1965 study of the relationship between truck welchts and truck speeds. The report was prepered from data obtained during the annue]. truck veight study performed by the Highway Planning Survey Section of the Indiens State Highway Coumiseion. The Joint Highway Research Project has cooperated in this study in a sinslar manner for many years.

The report is presented to the Bcard for information and the record. It is requested thst approvel be granted to distribute coples of the report to the Indiana State Highney Commission, the Bureau of Public Roads, the State Police, the Offlce of Mrafric SaPety, and the Mraflic Safety Foundation.

Reapectfully submitted,

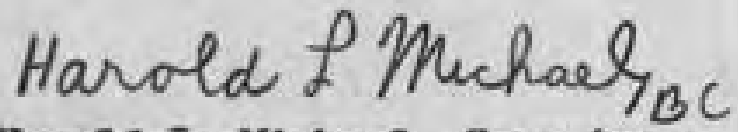
Harold I. Michael, Secretary

HIM: sat

Copy:

F. I. Ashbaucher

J. R. Cooper

J. W. Delleur

W. I. Dolch

W. H. Goetz

W. L. Greeco

F. F. Havey

F. S. H111

J. F. McIaughlin

F. B. Mendenhall
R. D. Msles

J. C. Oppenlander

W. P. Privette

M. B. Seott

J. V. Sluythe

B. W. Stubbs

K. B. Woods

E. Y. Yoder 


\section{Progress Roport}

TAFFIC SPISBD REHORT 10. 82

\section{ZRUCK VETGHR - SPESD STUDY}

婂

Darrell A. Wr-1ght

Graduate Agdrtant

Jolnt Highray Rasearoh Project

Ful No: 8-3-h

Project No: C-36-10D

Purtus Unilversity

Iafayetto, Indiana 


\section{thequell etroont}

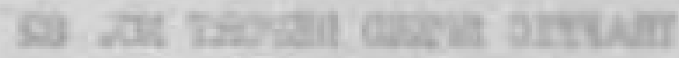
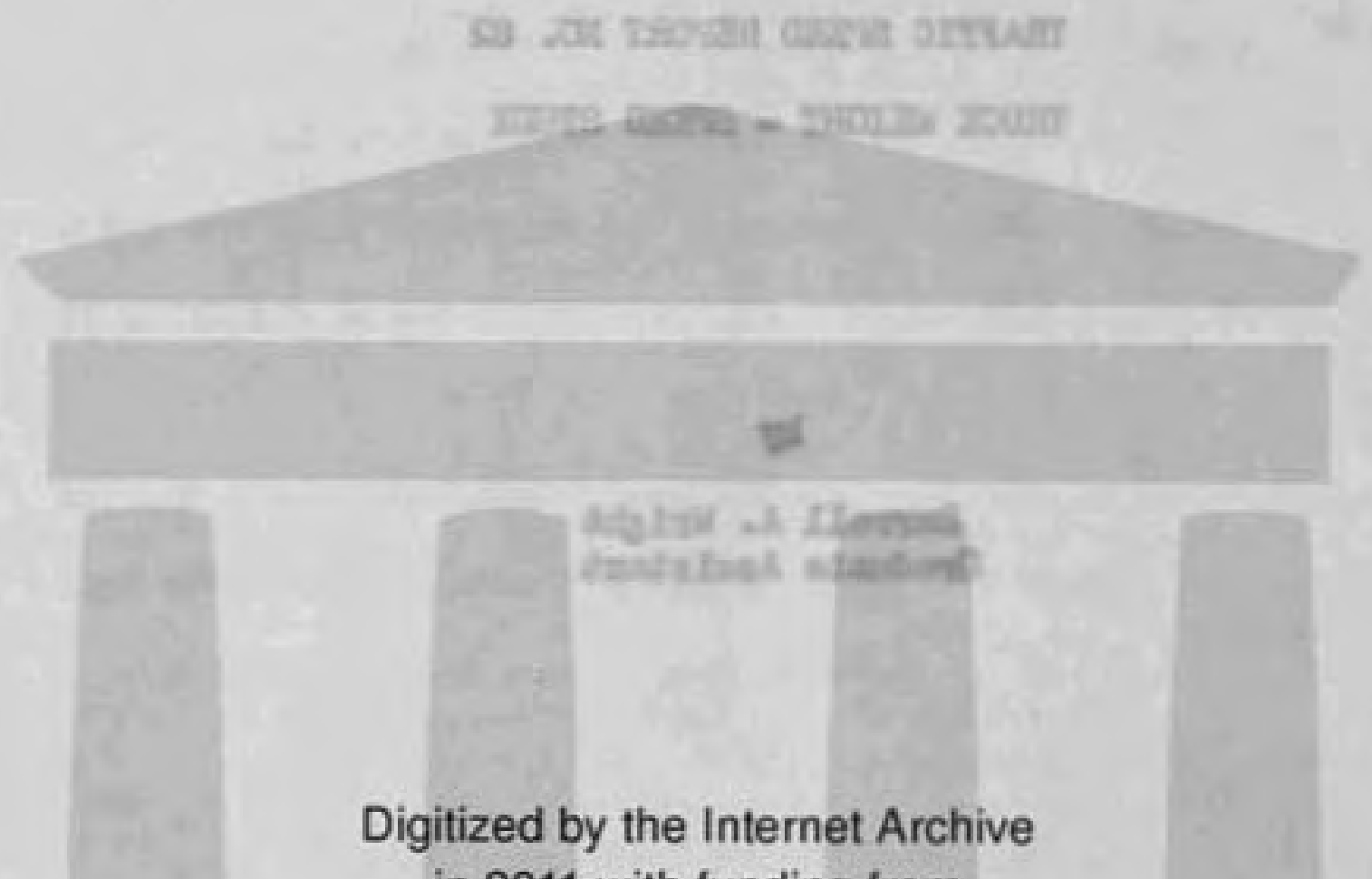

Digitized by the Internet Archive in 2011 with funding from

LYRASIS members and Sloan Foundation; Indiana Department of Transportation

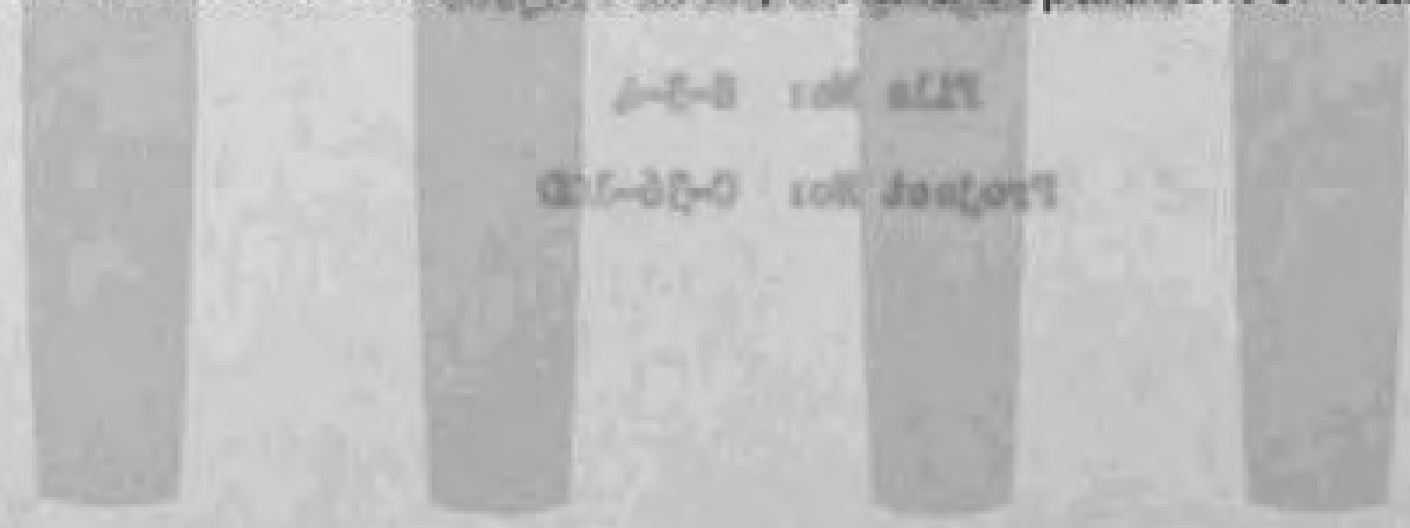




\section{ABSTRACT}

This report is the annund, continuing study of the relstionship between truck weicht and trucle speed. The weicht and speed of trucks on two-lane and four-lane hichways in Indiana vere taloen durlng August and September, 1965.

Analysis of the data indicated that as truels velght increased, trucle speed decreased allohtly. However, it vas found that the weifit of the truck only accounted for a rmall portion of the variability in truek apeeds.

The average opeede for trucles vere lower than the values for the provious study. Hovever, the trend in averaco speed still seems to be Increasing with the trend for beavler truciss on four-lane highrays tending to level near the speed linit. 


\section{TRAFFIC SPEABD REPPORT TOO, 82}

During the months of August and September the Hlifiva Planning Survey Section of the Indians State Highray Conmission conducted the anmual study of truck weights on Indiana highvays. The type of truck, weicht, size, and material hauled were recorded at twenty-three stations throuchout the state.

Th1s report is an anslysis of the 1965 trucls weight-speed data collected by personnel of the Joint H1 chway Research Project in cooperation with personnel of the Indians State Highray Commission. The truck weight-speed study compares the weifht of a truck, obtained by the Planning Survey Section through the use of loadometer and pit scales, and the speed of the same truck, obtained by the personnel of the Jolnt Highway Research Project, using a redar meter. The radar unst was located approudinately two miles from the welching site. A positive identiflcation method was used to metch the truck veight with 1 ts associated speed.

AIthough the Hiolway Planning Survey Section made observations at twenty-three locatilons throuchout the state, only ton stations were used for the collection of truck weicht-speed data. The ten stations are shown on Figure 1 and described as follows:

\begin{tabular}{|c|c|c|c|c|}
\hline tratson & Highray & Iocation & $\begin{array}{c}\text { Date of } \\
\text { Observation }\end{array}$ & $\begin{array}{l}\text { No. of } \\
\text { Ienes } \\
\end{array}$ \\
\hline $58 B$ & U.S. 32 & $\begin{array}{l}2000^{\prime} S_{\text {s of }} \\
\text { Southport Roed }\end{array}$ & Aug. 24 & 4 \\
\hline 75 & 0.8. 42 & $\begin{array}{l}0.25 \mathrm{Mi} \text {. S. or } \\
\text { U.S. } 42 \text { Business }\end{array}$ & Aug. 25 & 4 \\
\hline 83 & U.8. 41 & $\begin{array}{c}0.5 \mathrm{NH} . \mathrm{H}_{0} \text { of } \\
\text { S.R. } 37\end{array}$ & Aug. 26 & 4 \\
\hline 81. & U.S. 150 & $\begin{array}{c}0.3 \mathrm{Md}, \mathrm{S}_{0} \mathrm{~B}_{0} \text { of } \\
\mathrm{S}_{4} \mathrm{R}_{0} \mathrm{ST}\end{array}$ & Aug. 27 & 2 \\
\hline
\end{tabular}




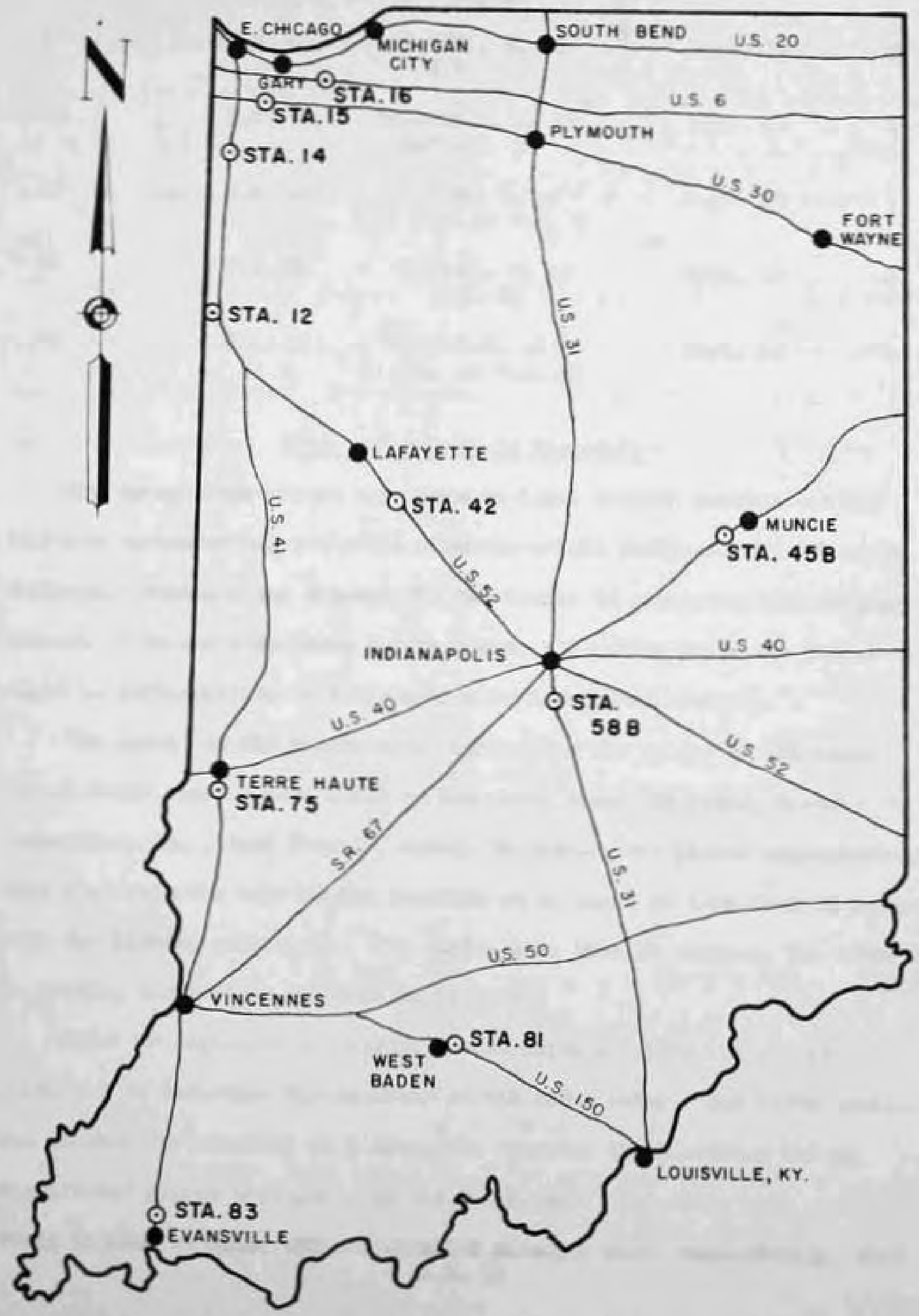

FIG. I LOCATIONS OF TRUCK WEIGHT-SPEED STATIONS 


\begin{tabular}{|c|c|c|c|}
\hline $45 B$ & S.R. 67 & $\begin{array}{c}1.0 \mathrm{NH} . \mathrm{S}_{3} \mathrm{H}, \text { of } \\
\text { Vuncle }\end{array}$ & Sept. 2 \\
\hline 16 & U.8. 6 & $\begin{array}{l}3.0 \mathrm{kt1} \text {. W. of } \\
\text { S.R. } 49\end{array}$ & Sept. 13 \\
\hline 25 & U.8. 30 & $\begin{array}{l}\text { Between } S_{0} \text {. R. } 55 \\
\text { and } S_{0} \text {. } 53\end{array}$ & Bept. 14 \\
\hline 14 & 0.8. 41 & $\begin{array}{l}0.5 \mathrm{MH} . \mathrm{S} \text { of } \\
\text { II. Jet. of S.R. } 2\end{array}$ & Sept. 15 \\
\hline 12 & 0.8 .52 & $\begin{array}{c}2.25 \text { vis. W. of } \\
\text { U.8. } 41\end{array}$ & Sept. 16 \\
\hline 42 & U.S. 52 & $\begin{array}{l}600^{\prime} S_{.} B_{3} \text { of } \\
\text { B. Jet. of } S_{.} R_{\text {. }} a 8\end{array}$ & Bept. 20 \\
\hline
\end{tabular}

\section{Bgulment and Fleld Procedure}

The speed observations were made cu lovel tangent sectlons of the hidnvays approdmately two mlles from the weicht stations. In all cases oufficlent afstance vas allowed for the trucics to regain normal erufising speeds. Care vas also talken not to choose a location there the trucka mllt be influenced by an intersection or a rallyoad crossing.

The speeds of the trucks vere obtained by the use of an "BlectroMatie" Radar Speed Meter, bullt by Automatie B10nal DIvis1on, Bastman Intustries, Inc., Bast Ilorvalk, Conn. The noter vas placed approcimately four feet from the edge of the pavement at an angle of loss than 10 decrees with the highwey centerline. For ancles loss than 10 decrees, the error In reaang the vahtole opced is negledble.

Prior to becinning the study, a test uoing a "fleth theel" vas perforned to deterndine the accuraey of the radar meter. The firth theel was checked for aocuracy at a IIve-mlle odoneter check section and no ofonificant errors vere foumd in the instrument. The radar unit vas found to have an error of less than $1 / 2$ mlle per hour; consequently, the 
use of a callibration curve was deemed unnecessary. During the observations at a station, the radar meter was checlea periodically with the 60 mile por hour tunting fork to assure the accuracy of the readings.

Bach truck for which a speed was recorded was free flowlng (the speed of the truck should not have been affected by other vehiclos travelIng in the same direction).

To avold influencing the vehicles on the facility; the vehicle which was used in the study was not parked on the roadside at the observation station. The vehicle was perised ca a side road in the vicinity of each station with an attermpt to conceal it from the viev of the passing vehicles.

The radar unst was placed on a platiorm in a creen cardboard barrel, simflar In size and color to the metal barrels used by the Indisms State Hifhway Department for roadside trash collection. The cable to the speed recording meter was stretched toward the roadside fonce. In this mamner, the personnel in the study were approximately 25 feet from the roadside and created a minimum influence on the passing trucks.

The truck welght-speed data were collected from $8 \mathrm{~A}_{0} \mathrm{M}_{0}$ to 4 P.M. During the four A.M. hours the weifolts and speeds vere recorded for trucles traveling in one disection, and during the four $\mathrm{P}, \mathrm{M}$. hours the information was recorded for trucles traveling in the opposite direction.

A positive method of identiflcation was used to match the truck weights recorded with the truck speeds. At the roight stations, in addition to the wolght of each truck, the name, the number of axcles, the color of the cab and trailer, the time that the truels left the weifht 
station, and any other 1dentifying features vere recorded. The same information was recorded for each truck that passed the radsr unit. By estimating the time required to travel from the veifht station to the radar unit and using the other 1dentifylng Peatures, the truck weights vere matched to the appropriate truck speed. If there was any doubt In the watching, the particular welght and speed were not used in the analysis.

\section{Anglysis}

For the purpose of annlysis the truclos were classified as single unft or multi-unit for each station: An analysis was made for each type of roadway, two-lane and four-lane. The single unit trucks were divided into those less than 5000 pounds and those 5000 pounds or creater. The veipht classiflcation corregponds to the Indiana speed limits:

65 MPH for 1ight trucks (less then 5000 poumds)

55 MPH for heavy trucles ( 5000 pounds or more) on 4-lane highways vith a median of 20 feet or more

50 MPH for heavy trucics on other rosdirys

To determine the relationship between truck wolght and truck speed for each classiflcation of trucle on each type of roadway, a linear equation was Pltted to the data using regression techniques, A weighted regression analysis program (VRAP) vas used for the recression analysis. The couputatIons were performed using the 7094 cormuter at Purdue University.

\section{Regults of Anglysis}

The observed values for truck veights at each station were separated Into 4,000 pound weight classes. Tables 1 and 2 show the number of trucks 


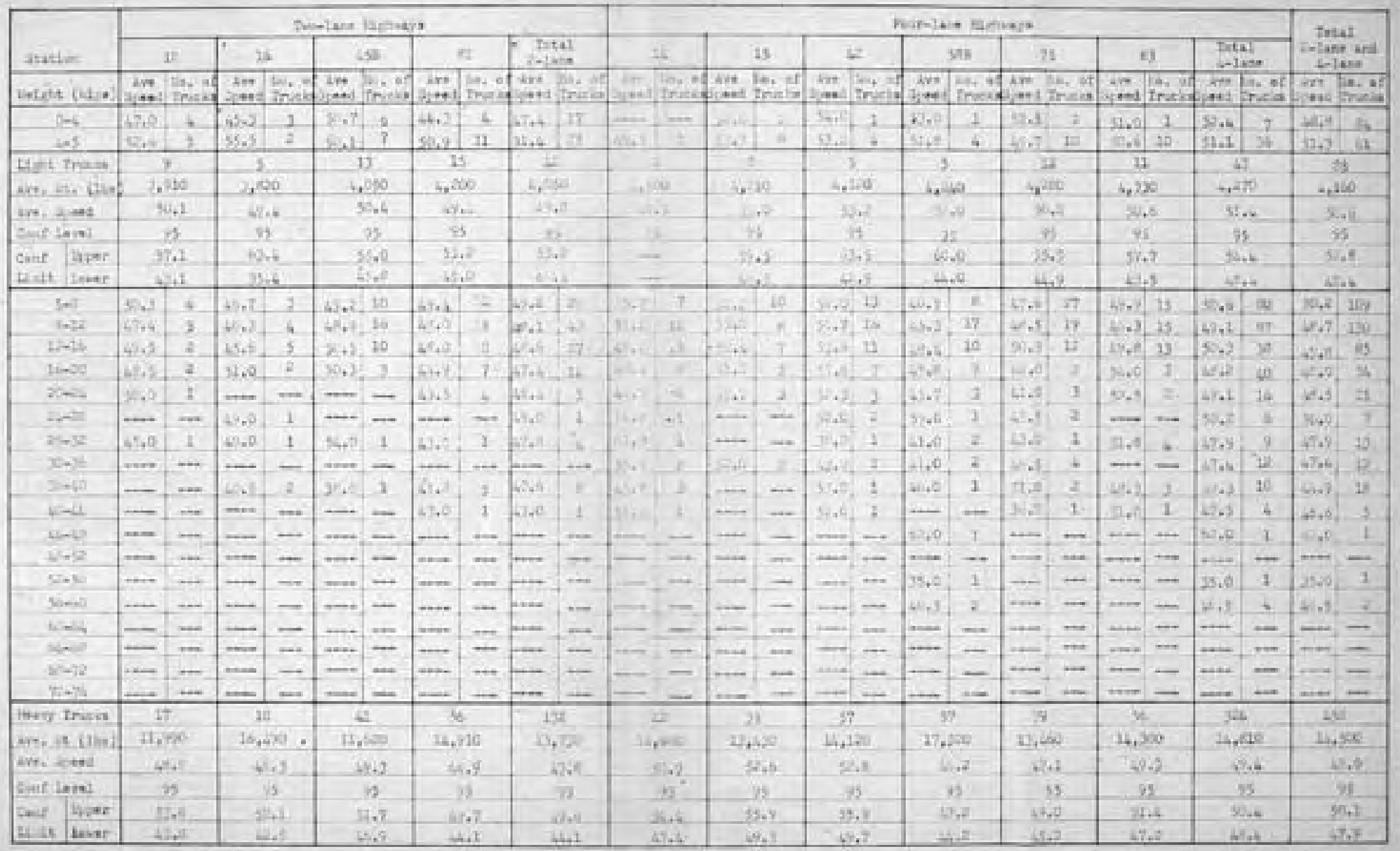




\begin{tabular}{|c|c|c|c|c|c|c|c|c|c|c|c|c|c|c|c|c|c|c|c|c|c|c|c|c|c|c|}
\hline \multirow{3}{*}{ 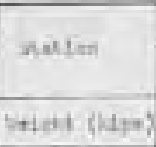 } & \multicolumn{10}{|c|}{ 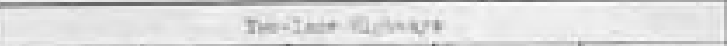 } & \multicolumn{14}{|c|}{ feit-ien flishops } & \multirow{2}{*}{\multicolumn{2}{|c|}{ 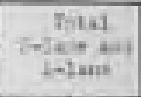 }} \\
\hline & \multicolumn{2}{|c|}{ w } & & \multicolumn{2}{|c|}{49} & \multicolumn{2}{|c|}{4} & \multicolumn{2}{|c|}{ Sula } & \multicolumn{2}{|c|}{ H } & \multicolumn{2}{|c|}{$7 !$} & \multicolumn{2}{|c|}{ is } & \multicolumn{2}{|c|}{ sen } & \multicolumn{2}{|c|}{ t3 } & \multicolumn{2}{|c|}{8} & \multicolumn{2}{|c|}{$\begin{array}{c}\text { fatut } \\
\text { tospiscer }\end{array}$} & & \\
\hline & dist. & Bring if & $\sin$ & Fisit & ind & Shing & 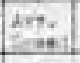 & ment & $\sin :$ & Gonst & $x=$ & 10.45 & {$\left[\begin{array}{ll}n+\infty \\
i \infty n\end{array}\right.$} & sicis if & fami & Iristive & $\lim$ & $\begin{array}{l}\text { As, of } \\
\text { inistif }\end{array}$ & $\sin t$ & tresing & ant: & Exiofial & int & Pone? & in: & $\lim \mid$ \\
\hline $3-12$ & 49.11 & 2 & $\cdots$ & -1 & $\ldots$ & - & $\ldots$ & - & 4200 & 3 & - & - & $\cdots$ & $\cdots$ & - & -1 & $\cdots$ & $-\infty$ & $\infty$ & - & $\cdots$ & $\cdots$ & $\cdots$ & $\ldots$ & 4.0 & 2 \\
\hline $17+10$ & $4 i 20$ & $t$ & 91.0 & f. & $m$ & $\rightarrow$ & $\cdots$ & $\rightarrow$ & 5,2 & 2 & $5 \%-\frac{1}{4}$ & $=$ & +1 & - & 262 & 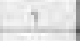 & $\operatorname{lin} 2$ & 1 & $\cdots$ & $m$ & - & $\cdots$ & werts & -4 & a) 2 & $?$ \\
\hline $10=0$ & Whes & $z$ & 420.2 & a & Kr. & 1. & 52,14 & 2 & tive & z & hi: & 1 & 9.7 & 1 & $18 * 4$ & I & $4,8$. & -2 & 8.3 & 2. & $2 \% 7$. & 2 & 500 & 3 & -7.5 & $n$ \\
\hline $20-46$ & 5.1 & 4 & 8.6 & if & 69.2 & \& & 48,7 & 2 & 4.6 & 1) & $\tan 2$ & (4) & 1. 1 & 18 & $E \cdot 2$ & 17. & 46.7 & 11 & $(3) .3$ & 1 & 6.24 & Ii. & $36 t$ & 75 & g.5 & 3 \\
\hline $26-36$ & 4.7 & I & 2.2 & 13 & 7,4 & $=\pi$ & $2 x+5$ & 1 & Ex: & at & $\mathrm{at}$ & 14 & tit? & 3 & e.ts & it: & s,in & A & 12.2. & II & an. & it & $2 a_{1} b^{-2}$ & $2 x$ & 4.2 & int. \\
\hline $26-2 z$ & Eis: & 3 & -2 & 3 & 57.3 & it. & 40.7 & 3. & 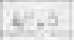 & 14 & 71 & $x$ & Fis? & 13 & 57.6 & A & 5.3 & 14 & 32.5. & 15 & 9,9 & 5 & y.2 & $10 \%$ & 54.2 & pon \\
\hline $3 . .6$ & W. & 18 & -7.2 & 3 & 6.5 & $=$ & $4+8$ & 1 & 68.1 & 1 & Xiti & 2) & 125.3 & 71 & S..) & 13 & 6.5 & 12 & 50.0 & 4 & 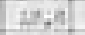 & 6 & 9.9 & 4 & $5 \pi, 4$ & 77 \\
\hline $3<4$ & 154 & 1. & 2.5 & it & 44.3 & 7 & L7.? & 1 & $A \cdot 2$ & IV & 96 & 34 & 20.5 & 3 & 58,7 & 10 & 69.7 & 9 & 69.7 & 3 & 32,4 ? & 4 & 5.1 & 17 & 31.1 & 35 \\
\hline ateis & 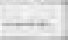 & 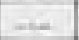 & se.s. & 35 & 11.3 & 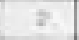 & 640. & 1 & 31.1 & 13 & at, 3 & 304 & A.s. & 10 & $53,=$ & at & 4.9 .0 & 3 & 6.5 & $z$ & 67.2 & 4 & 3t.81 & 4t & $5=9$ & 36 \\
\hline 44 & $\cdots$ & + & $\ldots-1$ & 5 & $y=5$ & 2 & $\ldots$ & + & 13.3 & $A$ & $55+2$ & 15 & 57.? & 74 & 27,7 & 4 & $5 \%+2$ & 4 & 4.,it & $z$ & 4.5 & $z$ & 5.0 & 7 & $517 ?$ & is \\
\hline $6 x^{2}$ & 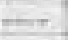 & $\cdots$ & x.1. & $y$ & niln & 2 & $30+1$ & 3 & 87,2 & 16 & 1. & s & p.7. & 7 & 69.7 & 5. & 4.9 & 31 & 4,0 & f & 58.4 & 5 & 47,2 & 45 & zost & ty \\
\hline- & E. & 2 & ix.? & 7 & $6: 2$ & t & 4.07 & 1 & F": & 2 & Wist & If & sin? & it & 13,7 & 1 & $67+2$ & 6 & L., f $^{3}$ & 3 & 34.5 & 3 & $4 \%+1$ & $\not 1$ & 400 & $\theta^{2}$ \\
\hline $30-6=$ & 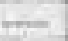 & - & *. & 10 & 4,0 & 2 & 41.9 & 1 & 8.: & $15^{\circ}$ & vit & 11 & y.t. & 2 & 5,1 & 12 & 90.3 & 6 & $-4+2$ & - & 85,4 & 11 & $x, 7$ & is & 30,5 & 17 \\
\hline ines: & 5.11 & $x$ & $91, ?$ & 13 & $\cdots$ & $=$ & 49 & I & A2+? & II & stait & IP & द.1. & 1 & 5.2 & 7 & 4,4 & 7 & $54+7$ & 3 & 5.5 & $\frac{2}{2}$ & $\times 4$ & 36 & 8,4 & 42 \\
\hline $14+4$ & - & $m$ & 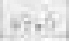 & H) & tivs & 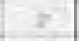 & सर, & 1. & 4.2 & 1) & $\cos$ & 3 & 3.7 . & 12 & $1=1$ & iI & $4+9$ & 10 & 51.6 & 5 & 53.7 & s & 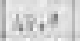 & 37 & 97.6 & $n$ \\
\hline (1) & 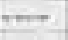 & - & 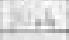 & 3 & 11,0 & 2. & wh & 1 & 36.2 & (1) & Eit & 31 & $2+2$. & 15 & $5 \div .1$ & 27 & 4.2 & 3 & 4.5 & 6 & $x+7$ & 17 & $4 t t^{2}$ & 7 & 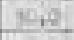 & iz \\
\hline$a^{4}$ & - 611 & 1 & 39,0 & $=$ & $(x+6)$ & $z$ & 4.6 & $=$ & 30.2 & ? & Wh+1 & 27 & 5.6 & 20 & $6 \% .1$ & 7 & $48+2$ & 25 & 350 & z & $78, \pi$ & 5 & 4.3 & of & 8,0 & $\pi$ \\
\hline$x=$ & - & $\cdots$ & - & $=$ & $34+2$ & $z$ & 4,4 & $z$ & $6 ?$ & 3 & stot & 7 & 8.5 & 1 & $2+4$ & 14 & 46.4 & 8 & 4,7 & 11 & - & - & 47.2 & 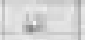 & Git. & 67 \\
\hline 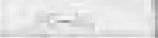 & $\longrightarrow$ & - & $\ldots$ & $\cdots$ & $\rightarrow$ & - & 4.2 & 2 & $45, ?$ & $i$ & $2+2$ & 2 & $\ldots$ & -. & 1.7 & 4 & $44^{6}$ & 1 & $\rightarrow$ & - & $\ldots$ & $\ldots$ & 6.2 & 9 & $14+5$ & 12 \\
\hline+1 & 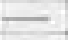 & $\cdots$ & $\cdots$ & $\cdots$ & ... & $\omega$ & $\rightarrow$ & $\cdots$ & $\cdots$ & - & 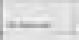 & - & $\ldots$ & $\cdots$ & - & $\omega$ & $\cdots$ & - & $\ldots$ & $\rightarrow$ & $\ldots$ & - & - & - & $\ldots$ & - \\
\hline 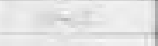 & $\rightarrow$ & $\cdots$ & $\ldots$ & $\omega$ & $\cdots$ & t. & $\ldots$ & - & $\ldots$ & $\ldots$ & $\ldots$ & $\ldots$ & $\omega$ & $\cdots$ & - & $\rightarrow$ & $\cdots$ & $\rightarrow$ & - & $\ldots$ & $\ldots$ & - & - & $\ldots$ & ... & - \\
\hline$i=$ & $\rightarrow$ & $\rightarrow$ & $\ldots$ & - & - & $\ldots$ & $\ldots$ & $\omega$ & $\cdots$ & $\cdots$ & $\cdots$ & $m$ & $\cdots$ & - & - & - & - & $\ldots$ & - & - & $\ldots$ & - & $\rightarrow$ & 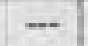 & - & - \\
\hline$-1 \times$ & $\cdots$ & $+m$ & $\ldots$ & - & 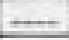 & + & $=$ & $=$ & $-\cdots$ & - & $\cdots$ & 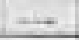 & $\longrightarrow$ & $\ldots$ & $\ldots$ & 1 & $\ldots$ & $=$ & $=1$ & - & $\cdots$ & -1 & - & $=$ & $m$ & - \\
\hline Detal fricile & 3 & & 11 & & 4 & & 7 & 5 & 22 & & $x=2$ & & ith & & ts & & $1 y_{0}$ & & 29 & & 98 & & 143 & & 12 & \\
\hline in un the? & 9. & & 67,1 & & 4,1 & & $4 x^{2}$ & 40 & $4, x^{2}$ & & $(47,38$ & & 0,7 & & 4. . & & 46,5 & & 46,4 & & 57,21 & & b., & & 4,9 & \\
\hline Int low & 4 & & 31. & & t. +2 & & 47. & 6 & 40 & & $34 a^{2}$ & & 50. & & 31. & & 4. & & $6 \%$ & & 51.3 & & 80,9 & & 29. & \\
\hline ent, lint & r & & $n$ & & $x$ & & t & is & *7? & & จ) & & is & & 85 & & * & & xf & & is & & 45 & & ys & \\
\hline cuet, bour & +8 & 4 & 38 & & 37 & & 8. & & 8. & & Fu & & He. & & 9. & & Wh. & & 86 & & $\mathrm{s.}$ & & 12. & & 97. & \\
\hline Lint Jover & 3. & & $\omega$. & & the & & w. & & 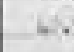 & & 20.6 & & s.t. & & $x=$ & & 67. & & ti. & & W\%. & & $56 \omega^{2}$ & & set & \\
\hline
\end{tabular}


and the average speed for each welfit class. The tables also show the averaos speed for each classifficatica of trucles at each station and sumbarles of the sarm values for each roaduay type. The results for each truek clnosifleation and roedvey type are as follows:

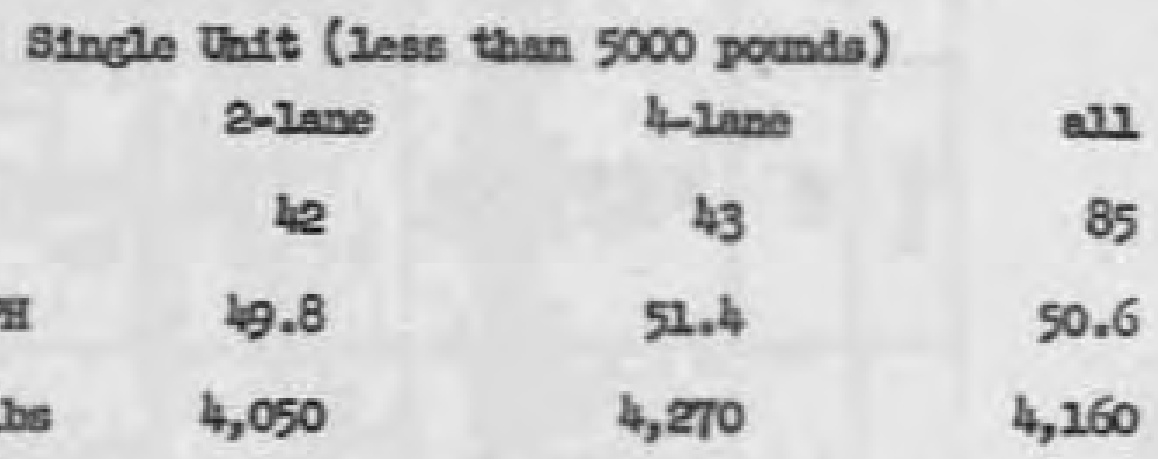

Wo. of vehicles

Single Unit (5000 lbe or more)

Average Speed - IPH

2-lane

4-lane

a11

Tlumber of trucka

132

326

458

Average Speed - MPII

47.8

Average Weloht - 1bs

13,730

Vorlts-Untt

49.4

14,810

49.0

14,500

2-Iane

4-lane

aI1

Number of trucics

222

943

1265

Average Speed - MPH

49.9

50.9

50.7

Average Weifht - Ibs

44,330

46,480

46, 070

The values in Table 3 are the percent of trucios exceeding the speed 1imit and the percent exceeding 5 miles above the apeed lint for each station. The folloring chart surmarizes the results in Table 3.

\section{Single Unit}

11ght

heavy

Vhalt-Unit

2-lane

Speed IAllt

5 apri above 11nt

2.4

0.0

32.1

6.2

48.6

9.0

4-lane

Speed 11mt

5 MCFi above lint

4.6

0.0

18.4

5.2

17.8

1.9 


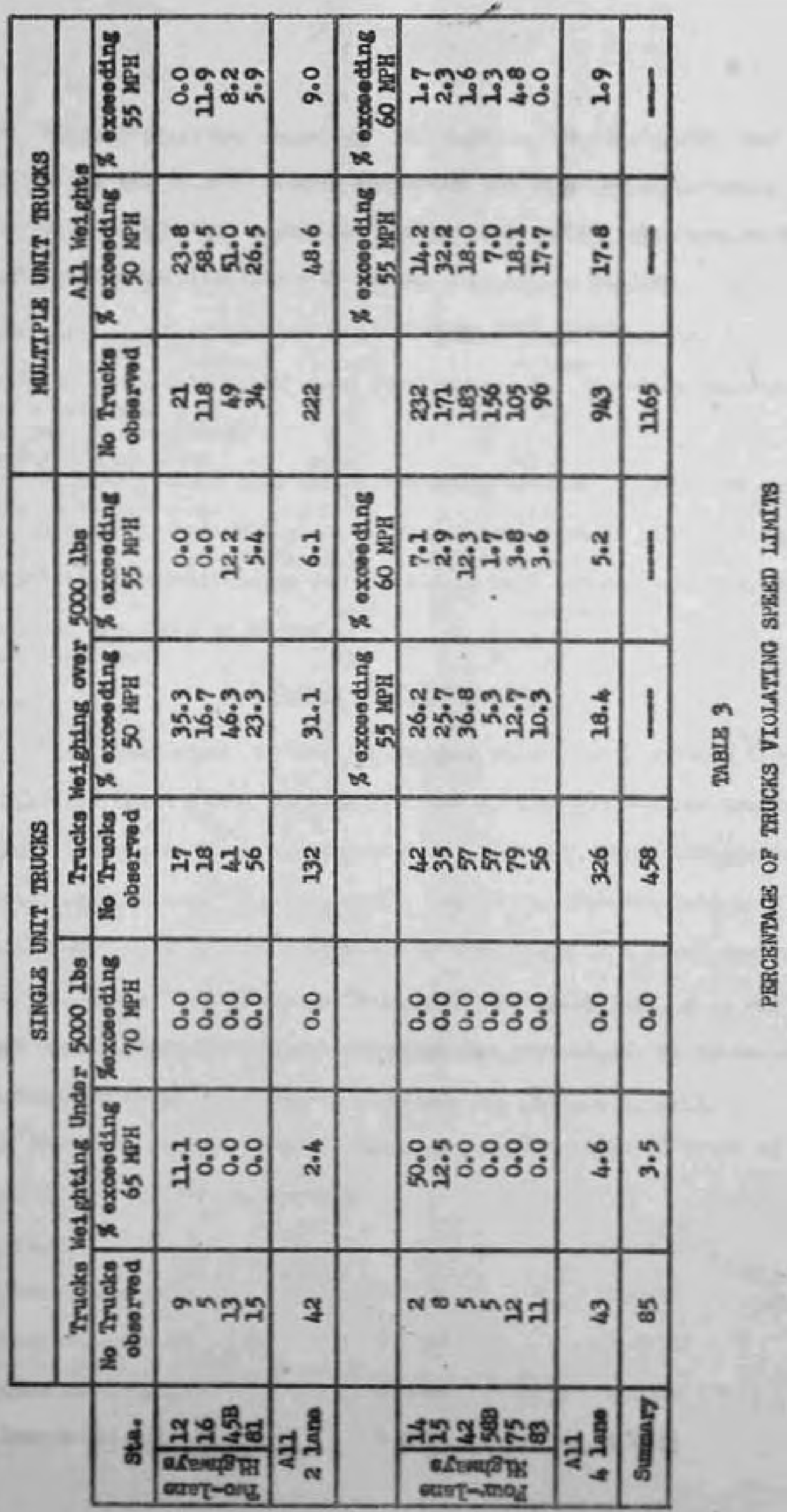


Table 4 lists the number of observations, average speed, and average weicht for each truck classiflcation for the past seventeen years.

Floures 2, 3 and 4 show Eraphically the accumulative speed distributIon for each classification of truck on two-lane, four-lane, and the combination of both roadray types. Figures 5 and 6 show the trends in the 85 th percentile truck speed for tro-lane and four-lane roadrays for the past twelve years.

Figures 7 and 8 show the relationship between truck weight and speed for single unit and milti-unit trucles on each type of roadway. The weight-speed relationships for all single unit and multi-unit trucks observed are ahown In Figure 9.

\section{Summary and Conclusions}

The Inear equations derlved for the relationship between truck welcht and truck speed, FIGures 7, 8 and 9, Indicate that as truck weicht increases, truck speed decreases. However, the coeffleients of Iinear association, " $r$ ", were small, Indicating that the data have a amall relation to a linear equation or that there is a great deal of scatter in the data. The coefflclents of determination, " $x^{2,}$, were also small. This coefficient expresses the percent of the varlablitty In the data which the equation explains.

The coeffleients computed for each classiflcation of truck on each type of roadtwa were as follows:

\section{Equation}

2-lane single unit

4-1ane single unit

2-lane multi-unit

4-1ane multi-unit

$$
x
$$

$x^{2}$

0.3030

0.0918

0.1320

0.0174

0.0084

0.0001

0.2516 


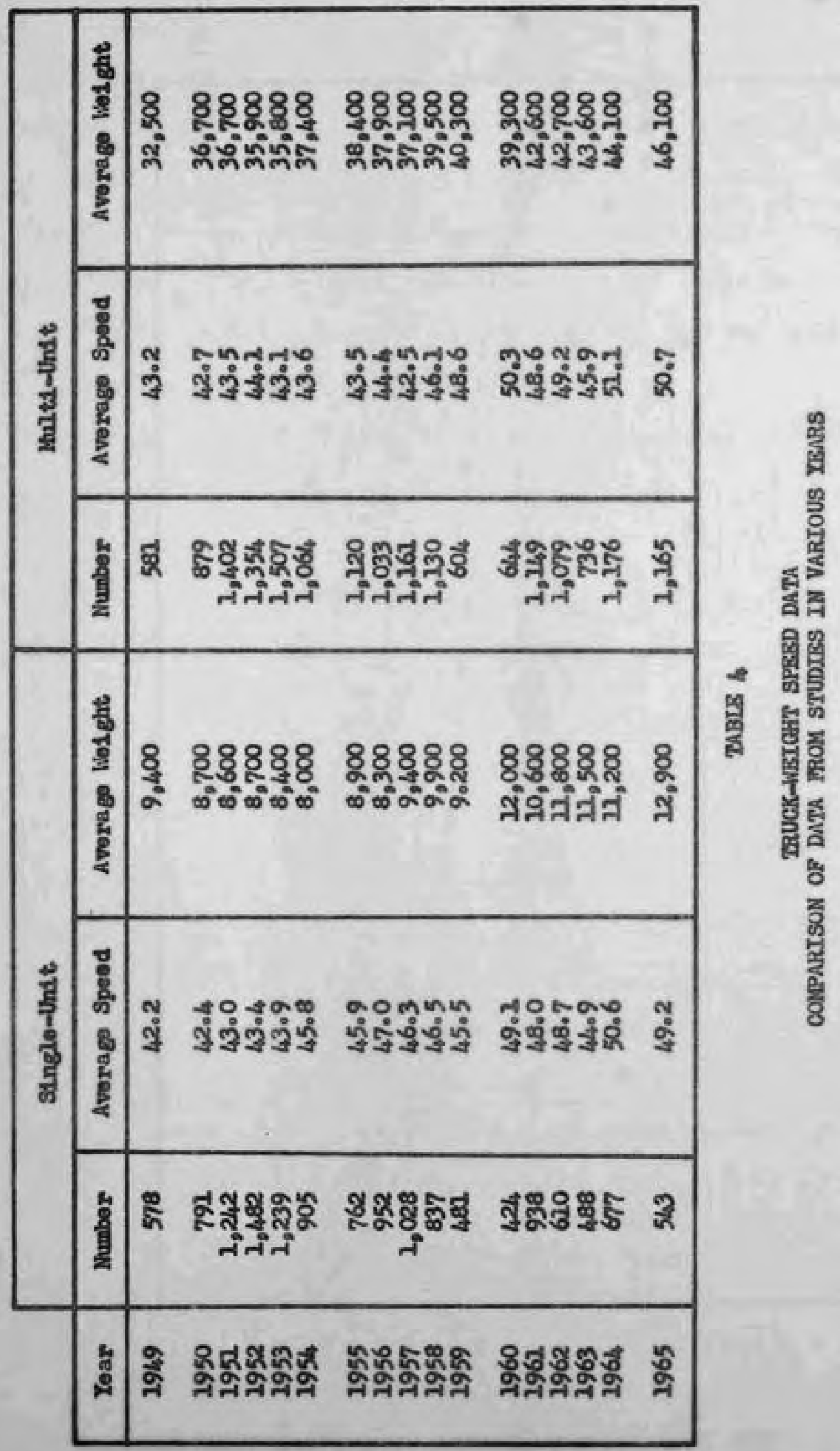




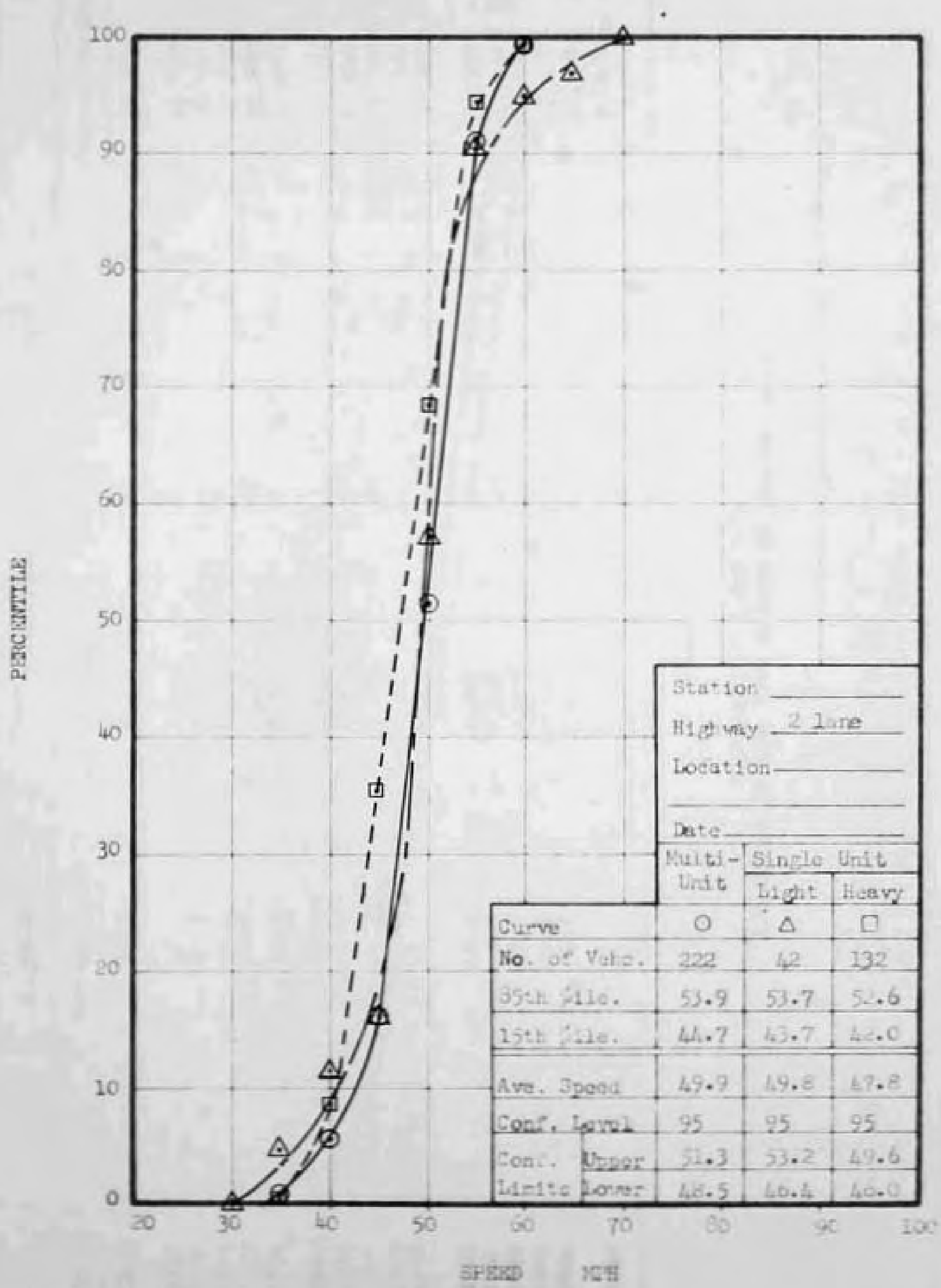

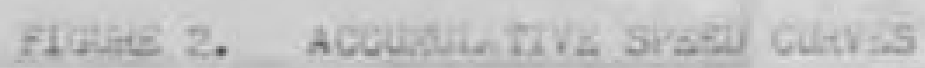




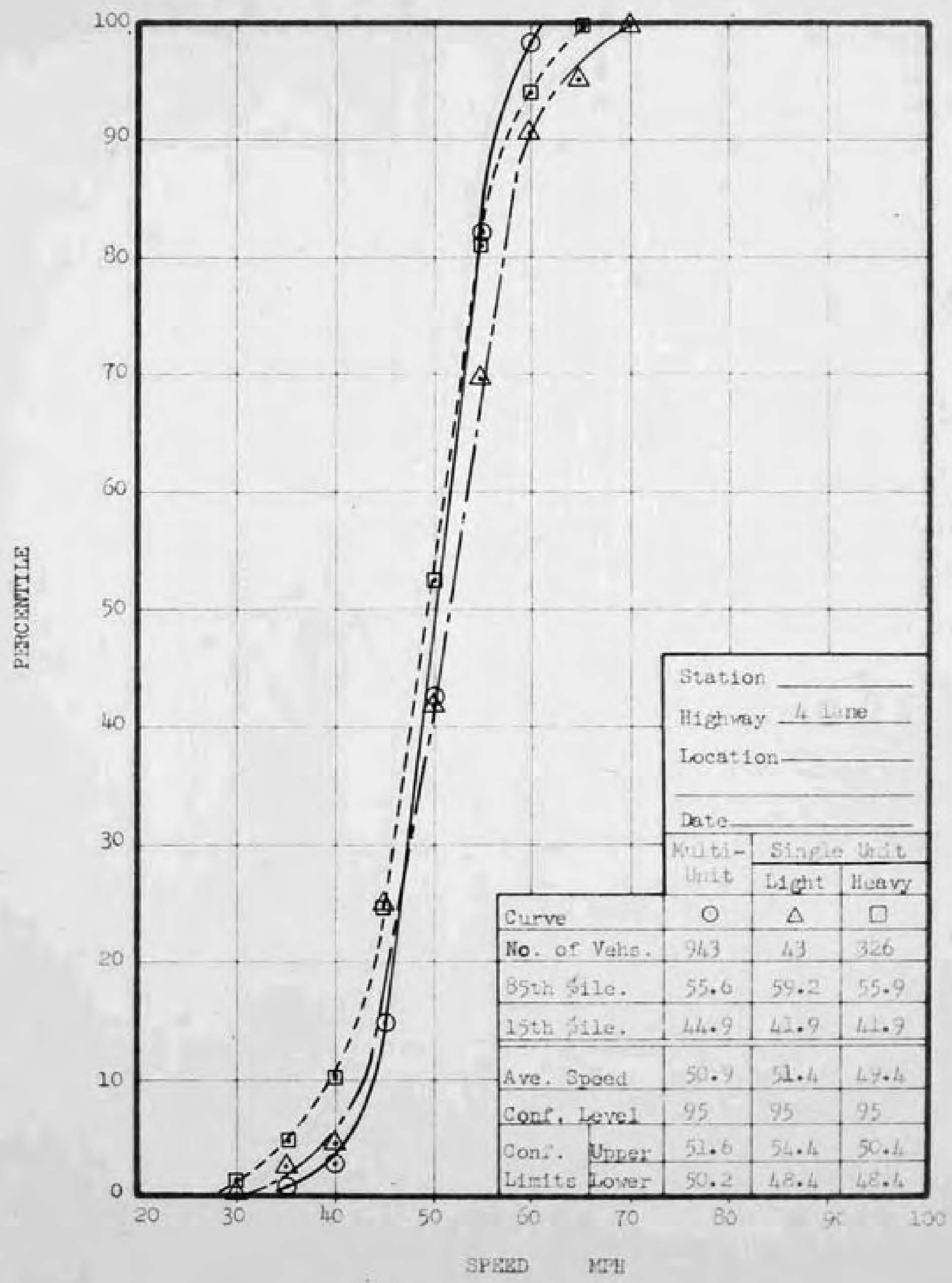

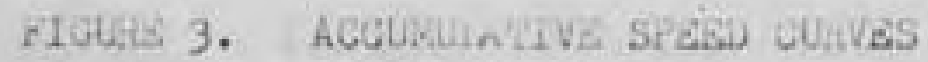




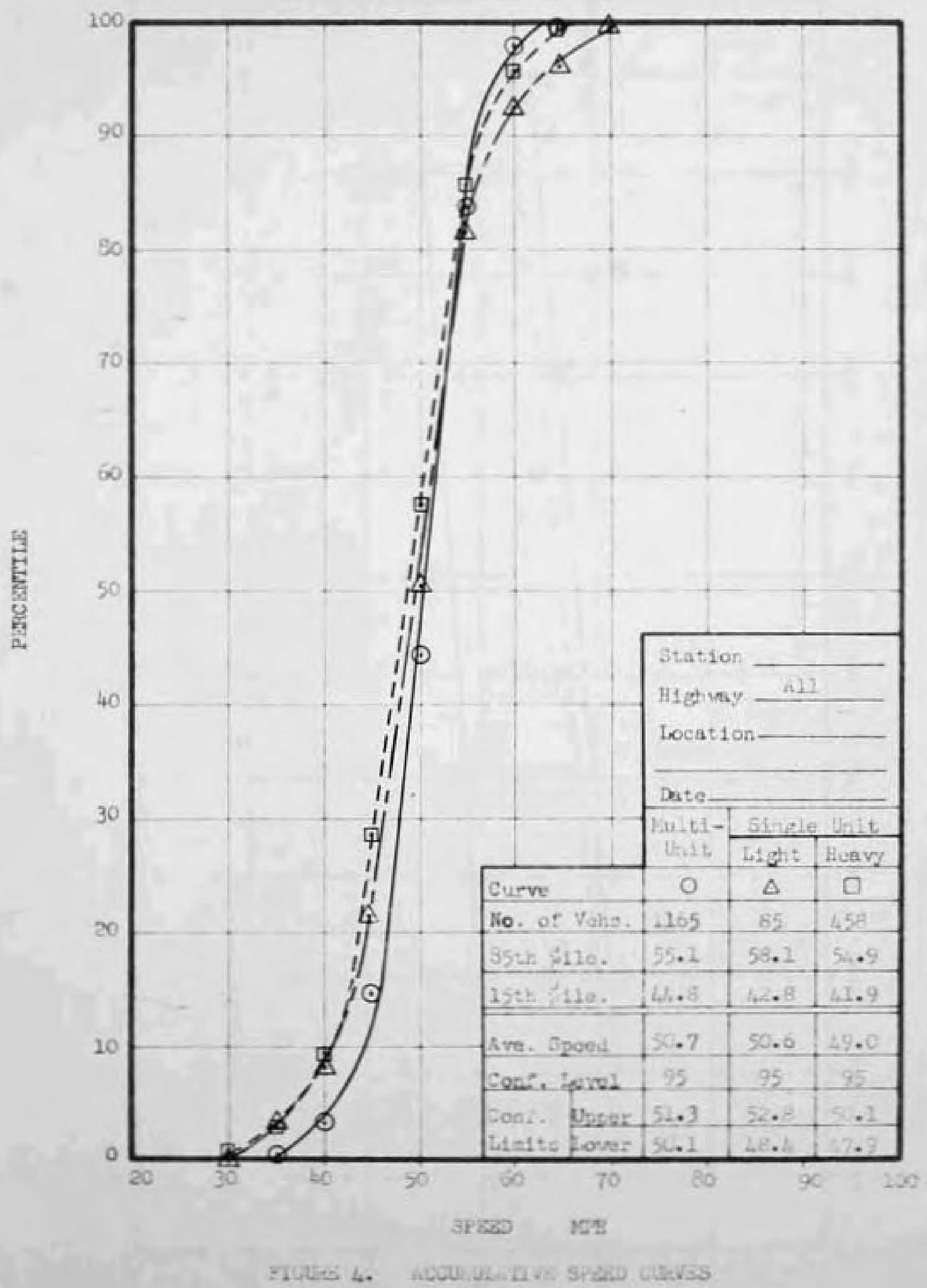




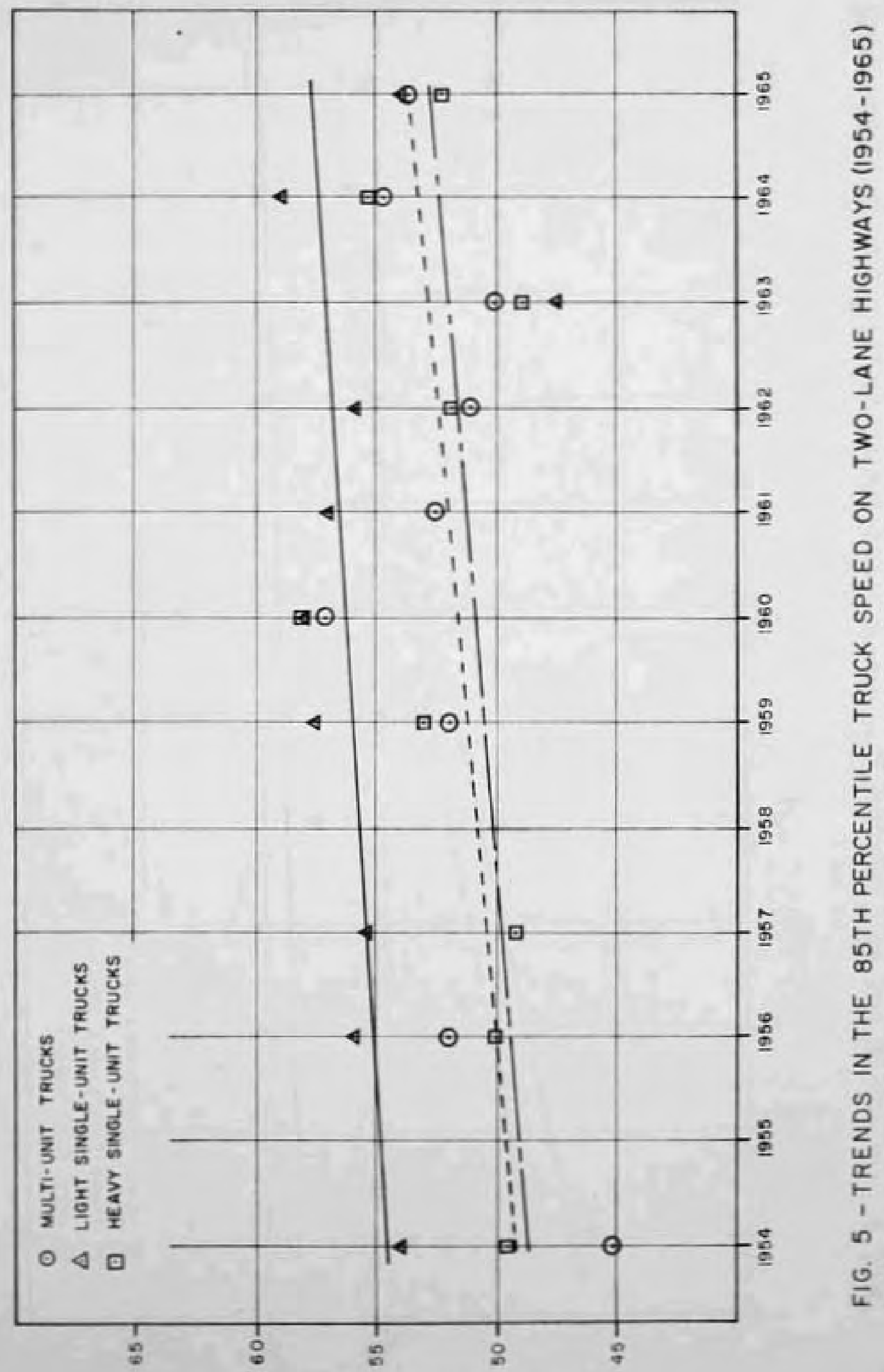

(Hdw) 033dS 3าแN3ว43d H1S8 


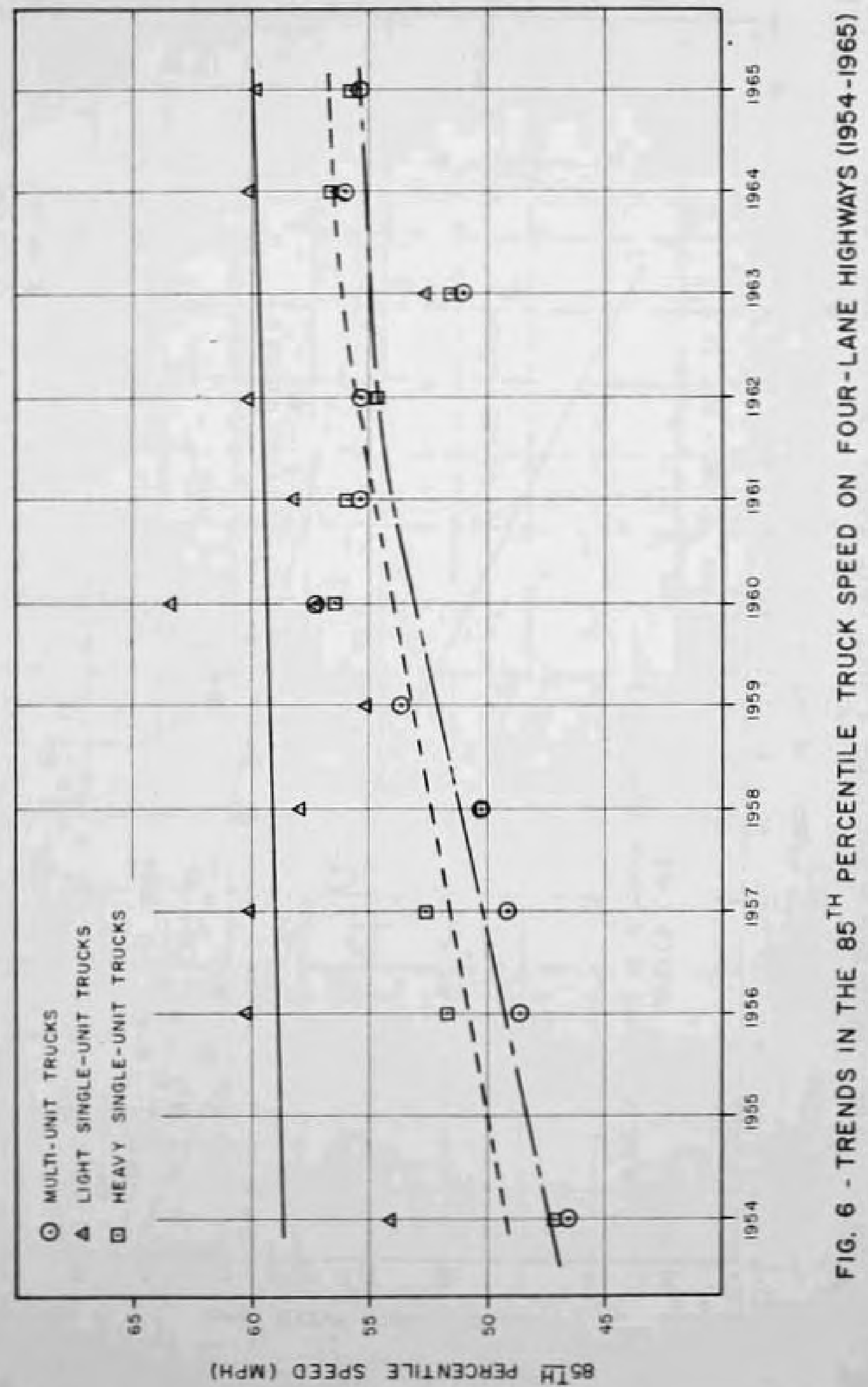




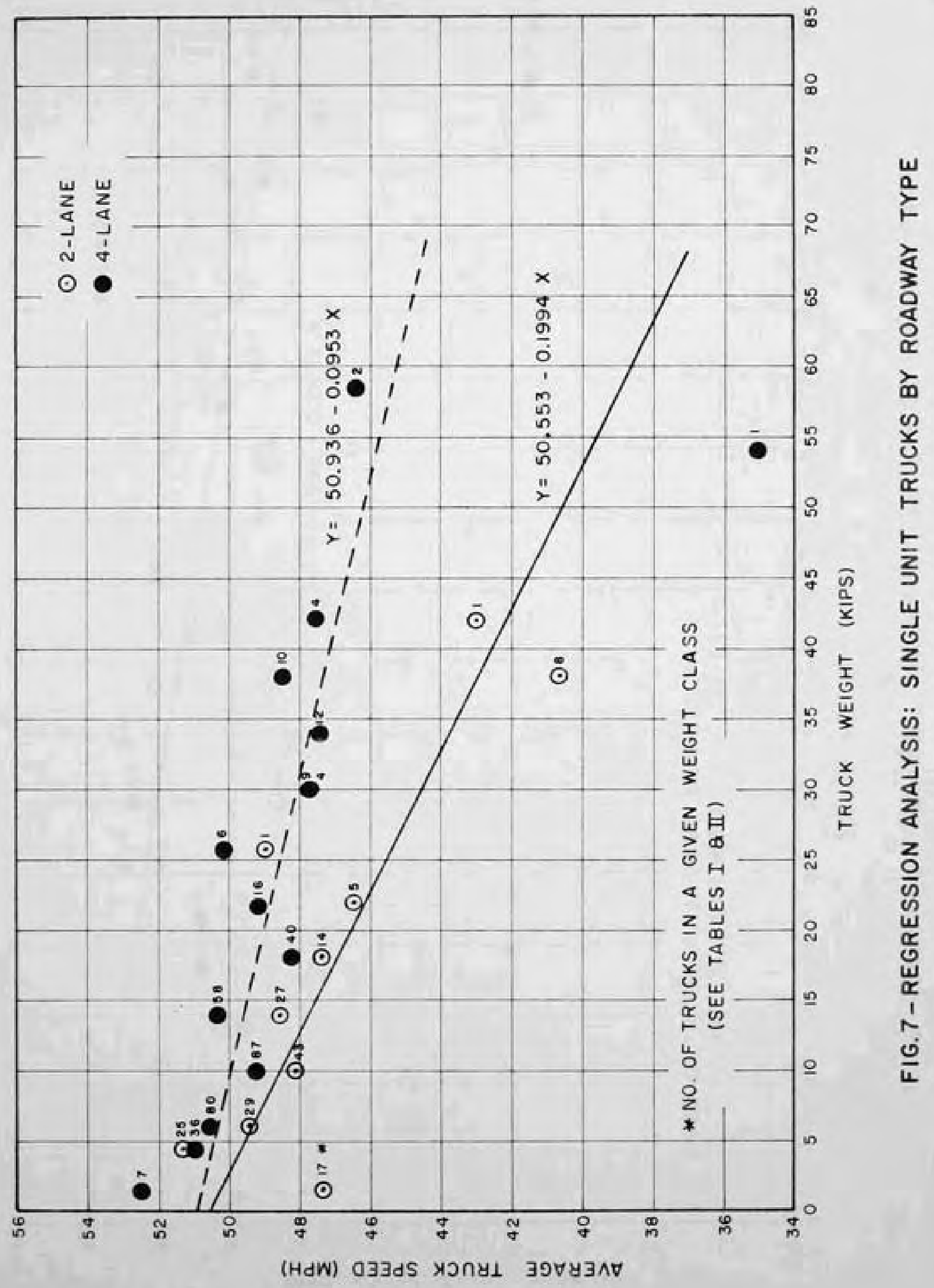




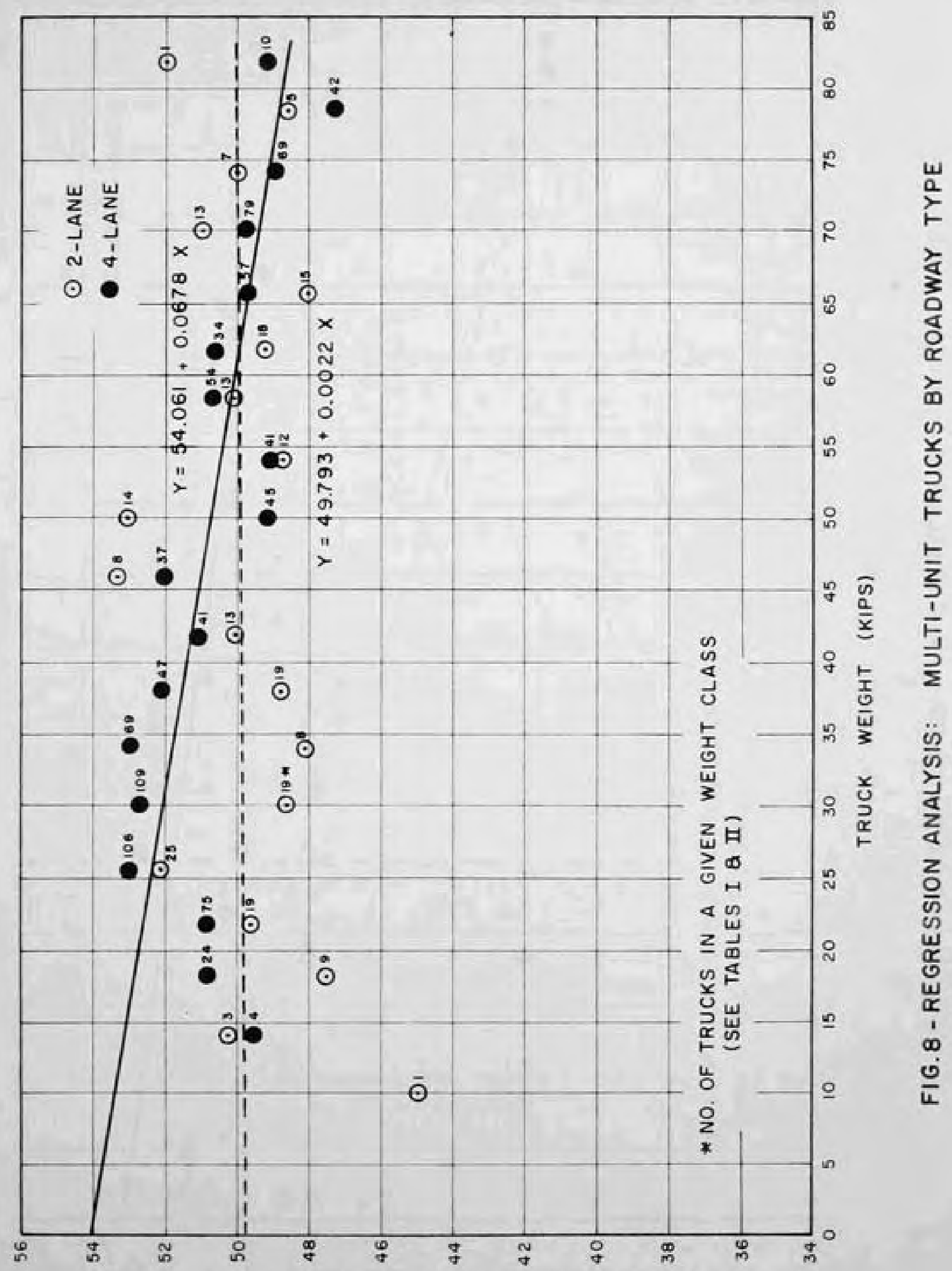

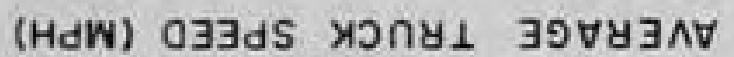




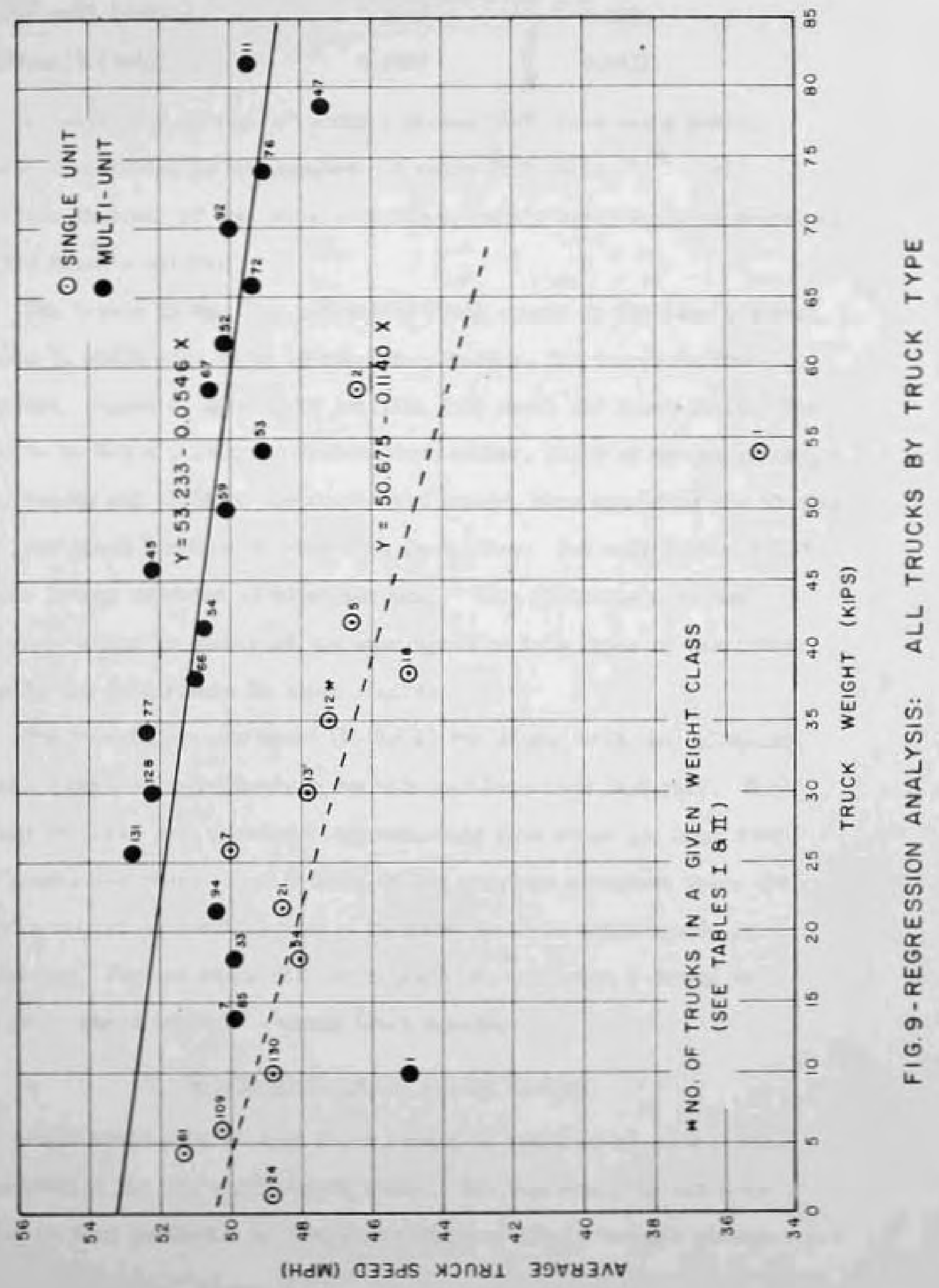




$\begin{array}{lll}\text { single unit (totel) } & 0.1618 & 0.0271 \\ \text { Inulti-unit (totel) } & 0.2027 & 0.0412\end{array}$

A positive 1.00 for " $r$ " would indseate that there was a positive Iinear association in the samples. A vatue of 1.00 for " ${ }^{21 "}$ would Indicate that all of the varlability in a truck's speed could be explatined by the truck's weicht.

The trends in the 85th percentile truck speeds on two-lane highways, Flgure 5, st1Il seem to be increasing. Whereas, the trends on four-lane h1 Ghrays, Figure 6, seem to be loveling just above the speed-1imit. The reaults in Mable 3 indicate that a large number, $31.1 \%$ of the heavy sincle unst trucks and $48.6 \%$ of the multi-unit trucles, were exceeding the 50 mile per hour speed 2imit on the two lane facilities. But only $6.1 \%$ and $9.0 \%$ of the trucks exceeded 55 mlies per hour. This Indicates a tendency for many trucks to travel at the same speed on both types of facllitiles despite the differences in speed limits.

The overall average speed (Table 4) for single unit and multi-unit truclos decreased approudmately one mile per hour from last year. The values for last year increased approxdmately flve miles per hour from the proceeding year. When results of the previous seventeen years are considered, it is doubtrul that a donmrard trend in truck speeds is beginning. Further otudy will be requiled to determine a change in the past upvard trend in average truck speeds.

\section{Beccimandations for Puture Studies}

1. Welght station 81 at West Baden should be replaced by another twolane station for the weicht-speed study. The topography in the area makes it very difficult to find a satisfactory level, tangent section 
to record the truck opoeds.

2. A 50 root extension cord should be purchased for the radar meter. This would recllitate concealing the personnal recording the opeeds of the passing trucks. Mruck arivers seem vory proflelent at detecting unusunl ectivitios, such as, a radar unit, 